\title{
Hubungan Pola Asuh dengan Perilaku Bullying pada Remaja SMP Negeri 19 Kota Jambi
}

\author{
Mohd. Syukri \\ Jurusan Keperawatan Politeknik Kesehatan Kemenkes Jambi \\ Correspondence email : mohd.syukri15@poltekkesjambi.ac.id
}

\begin{abstract}
Abstrak. Prevalensi bullying diperkirakan 8 hingga 50\% di beberapa negara Asia, Amerika, dan Eropa (Soedjatmiko, 2013). Hasil riset yang dilakukan oleh National assocition of School Psychologist menunjukkan bahwa lebih dari 160.000 remaja di Amerika Serikat bolos sekolah setiap hari karena takut di bullying (Sari, 2010). KPAI mencacat 369 pengaduan terkait bullying di sekolah. Bullying bisa terjadi saat seseorang mengalami bentuk pelecehan dan penghinaan yang secara sistematik dan menyakinkan selama periode waktu yang cukup lama (9-16 hari dalam satu bulan), tidak menutup kemungkinan terjadinya dirumah akibat pola asuh yang tidak tepat. Penelitian ini bertujuan untuk mengetahui hubungan pola asuh dengan perilaku bullying di sekolah. Desain penelitian crossectional. Sampel berjumlah 98 orang dengan tehnik pengambilan sampel proportional random sampling. Hasil penelitian menunjukkan ada hubungan bermakna antara pola asuh dengan prilaku bullying ( $\mathrm{p}$ value $\leq$ 0.05). pola asuh otoriter dan permisif memiliki kecenderungan yang lebih besar terjadinya periaku bullying pada anak.
\end{abstract}

Kata kunci : Bullying; pola asuh; demokratik; otoriter; permisif

Abstract. The prevalence of bullying is estimated at 8 to $50 \%$ in several Asian, American and European countries (Soedjatmiko, 2013). The results of research conducted by the National Association of School Psychologist showed that more than 160,000 adolescents in the United States skipped school every day for fear of bullying (Sari, 2010). KPAI has identified 369 complaints related to bullying at school. Bullying can occur when a person experiences forms of harassment and humiliation that are systematic and convincing for a long period of time (9-16 days in a month), does not rule out the possibility of occurring at home due to inappropriate parenting. This study aims to determine the relationship between parenting and bullying behavior in school. Crossectional research design. The sample amounted to 100 people with proportional random sampling sampling techniques. The results showed that there was a significant relationship between parenting and bullying behavior ( $p$ value <0.05). Authoritarian and permissive parenting tend to have a greater tendency to bullying children.

Keywords: Bullying; parenting; democratic; authoritarian; permissive

\section{PENDAHULUAN}

Bullying merupakan fenomena yang besar di seluruh dunia. Prevalensi bullying diperkirakan 8 hingga $50 \%$ di beberapa negara Asia, Amerika, dan Eropa (Murtiarni, 2013). Hasil riset yang dilakukan oleh Natonal assocition of School Psychologist menunjukkan bahwa lebih dari 160.000 remaja di Amerika Serikat bolos sekolah setiap hari karena takut di bullying. Lembaga swadaya masyarakat (LSM) Plan International dan Intertnational Canter for Research on Women (ICRW), menemukan bahwa tujuh dari 10 anak di Indonesia terkena tindak kekerasan disekolahan, menurut hasil kajian Konsorsium Nasional Pengembangan terjadi Sekolah Karakter pada 2014, hampir setiap sekolah di Indonesia terjadi bullying dalam bentuk verbal maupun psikologis/ mental. Berdasarkan pemaparan kasus bullying yang kompleks tersebut, Indonesia sudah masuk katagori darurat bullying di sekolah (Annisa, 2014).

Komisi Perlindungan Anak Indonesia (KPAI), kasus bullying di sekolah menduduki tingkat teratas dari pengaduan masyarakat ke KPAI di sektor pendidikan, dari tahun 2011 sampai Agustus 2014 KPAI mencacat 369 pengaduan terkait masalah tersebut. Jumlah tersebut sekitar $25 \%$ dari total pengaduan dibidang pendidikan sebanyak 1.480 kasus (Setyawan, 2015). Sepanjang 2018 tercatat kasus kekerasan terhadap anak mencapai rekor tertinggi sebanyak 336 kasus di wilayah Propinsi Jambi dengan rincian Kabupaten Kerinci berjumlah 30 kasus, Merangin 39 kasus, Sarolangun 18 kasus, Batanghari 27 kasus, Muaro Jambi 75 kasus, Tanjabtim 12 kasus, Tanjabbar 31 kasus, Tebo 6 kasus, Muaro Bungo 8 kasus, Sungai Penuh 24 kasusdan Kota Jambi 96 kasus (DP3AP2 Provinsi Jambi, 2018).

Perilaku bullying tersebut tidak luput dari faktor penyebabnya, seperti faktor internal dalam dirinya yaitu; harga diri dan kepribadian. Septrina, Liow, Sulistiyawati \& Andrian (2009) mengatakan dalam penelitiannya bahwa semakin tinggi harga diri maka semakin rendah perilaku bullying. Tumon (2014) juga menambahkan ada 3 faktor eksternal yang dapat mempengaruhi terjadinya bullying, yaitu keluarga, sekolah dan teman sebaya. Keluarga merupakan faktor yang paling berpengaruh terhadap kejadian bullying (Ahmed \& Britewate, 2014). Faktor keluarga yang paling menentukan adalah pola asuh.

Pola asuh adalah cara orang tua menjalankan perannya terutama dalam mendidik anaknya, mulai dari membuat aturan, mengajarkan nilai/ norma, dan kasih sayang. Salah satu yang mempengaruhi pola asuh adalah 
lingkungan tempat tinggal. Perbedaan keluarga yang tinggal di kota besar dengan keluarga yang tinggal di pedesaan berbeda gaya pengasuhnya. Keluarga yang tinggal di kota besar meiliki kekhawatiran yang besar ketika anaknya keluar rumah, sebaiknya keuarga yang tinggal didesa tidak memiliki kekhawatiran yang besar dengan anak yang keluar rumah. Dalam setiap budaya pola asuh yang diterapkan berbeda-beda, misalnya ketika disuatu budaya anak diperkenankan beragumen tetang aturan-aturan yang ditetapkan orang tua, tetapi hal tersebut tidak berlaku untuk semua budaya. Keluarga yang memiliki status sosial ekonomi yang berbeda juga akan menerapkan pola asuh yang berbeda.

Menurut Rigby (2008) yang menjelaskan bahwa bullying katagori sedang (intermediatte) secara langsung atau tidak, disadari maupun tidak disadari terjadi dirumah selama anak dalam asuhan orang tua bisa dalam bentuk pelecehan dan penghinaan yang secara sistematik dan menyakinkan selama periode waktu yang cukup lama (9-16 hari dalam satu bulan) sudah dapat menjadikan pengalaman traumatik bagi anak dan menjadi dasar munculnya perilaku bullying. Disekolah bentuk tindakannya meliputi ejekan yang kejam, pengucilan yang berkelanjutan dan beberapa ancaman dan serangan fisik yang halus, contohnya mendorong, menjegal, menarik baju. Beberapa hal yang bisa menjadi indikasi awal bahwa anak kemungkinan sedang mengalami bullying disekolah antara lain: kesulitan untuk tidur, mengompol ditempat tidur, mengeluh sakit kepala atau perut, tidak nafsu makan atau muntahmuntah, takut pergi kesekolah, menangis sebelum atau sesudah kesekolah, sering pergi ke UKS, tidak tertarik pada aktifitas sosial yang melibatkan murid lain, sering mengeluh sakit sebelum pergi ke sekolah, sering mengeluh sakit kepada gurunya, dan ingin orang tua segera menjemput pulang, harga dirinya rendah, perubahan drastis pada sikap, perilaku, cara berpakaian, atau kebiasaannya.

Perilaku bullying tersebut bisa mengakibatkan pengaruh negatif terhadap status psikologis, baik dalam jangka pendek dan jangka panjang pada korbannya (Fekkes dkk., 2006; Milsom \& Gallo, 2006; Roberts, 2005 dalam Santrock, 2011). Dalam jangka pendek, mereka bisa menjadi tertekan, kehilangan minat dalam tugas sekolah atau tidak ingin pergi sekolah. Sedangkan jangka panjang anak bisa mengalami kecemasan, depresi, hingga tindakan bunuh diri. Remaja yang menjadi korban bullying lebih berisiko mengalami berbagai masalah kesehatan, baik secara fisik maupun mental. Adapun masalah yang lebih mungkin diderita anak-anak yang menjadi korban bullying, antara lain munculnya berbagai masalah mental seperti depresi, kegelisahan dan masalah tidur yang mungkin akan terbawa hingga dewasa, keluhan kesehatan fisik, seperti sakit kepala, sakit perut dan ketegangan otot, rasa tidak aman saat berada di lingkungan sekolah, dan penurunan semangat belajar dan prestasi akademis.

\section{METODE}

Penelitian ini adalah penelitian kuantitatif crossectional. Teknik pengambilan sampel secara proportional rendom sampling. Penelitian dilakukan untuk menganalisa hubungan pola asuh dengan perilaku bullying. Sampel berjumlah 100 orang. Instrumen berupa kuesioner yang digunakan untuk mengukur perilaku bullying dan pola asuh. Pengolahan data dengan editing, coding, processing dan cleaning. Analisis statistik yang dipergunakan yaitu univariat dan bivariat dengan uji Chi Squere. Etika penelitian yang digunakan peneliti Maleficience, Justice, Anomymous, Beneficence dan Informed concent.

\section{HASIL DAN PEMBAHASAN \\ Data Demografi}

Gambaran data demografi responden dapat dilihat sebagai berikut:

Tabel 1. Distribusi responden berdasarkan data demografi

\begin{tabular}{|c|c|c|c|}
\hline No & Data & $\mathbf{f}$ & $\%$ \\
\hline \multirow[t]{3}{*}{1} & Umur & & \\
\hline & Remaja awal (12-16 th) & 96 & 97.9 \\
\hline & Remaja akhir (17-25 th) & 2 & 2.1 \\
\hline \multirow[t]{3}{*}{2} & Jenis kelamnin & & \\
\hline & Laki-laki & 57 & 58.2 \\
\hline & Perempuan & 41 & 41.8 \\
\hline \multirow[t]{4}{*}{3} & Kelas & & \\
\hline & VII & 30 & 30.6 \\
\hline & VIII & 32 & 32.7 \\
\hline & IX & 36 & 36.7 \\
\hline \multirow[t]{4}{*}{4} & Posisi Anak & & \\
\hline & Sulung & 51 & 52.1 \\
\hline & Tengah & 17 & 17.3 \\
\hline & Bungsu & 30 & 30.6 \\
\hline \multirow[t]{4}{*}{5} & Pendidikan ortu & & \\
\hline & Rendah & 42 & 42.9 \\
\hline & Menengah & 33 & 33.7 \\
\hline & Tinggi & 23 & 23.4 \\
\hline \multirow[t]{4}{*}{6} & Pekerjaan ortu & & \\
\hline & PNS & 27 & 27.5 \\
\hline & Swasta & 39 & 39.8 \\
\hline & Buruh & 32 & 32.7 \\
\hline
\end{tabular}

Berdasarkan data tebel tersebut, karaktersitik responden menurut umur didominasi oleh usia remaja awal yang menurut Depkes ada pada rentang 12 sampai 16 tahun. Laki-laki lebih banyak 6,4 \% dibanding perempuan. Kelas IX lebih banyak mewakili responden karena secara jumlah lebih banyak dibanding kelas lainnya. Status sebagai anak sulung lebih banyak dijumpai pada responden. Pendidikan orang tua lebih banyak masih dalam kategori rendah dengan status pekerjaan swasta.

\section{Gambaran pola asuh orang tua responden}

Secara umum bagaimana penerapan pola asuh orang tua terhadap remaja di SMP 19 Kota Jambi dapat dilihat pada tebel beriku 
Tabel 2. Distribusi responden berdasarkan pola asuh orang tua

\begin{tabular}{crr}
\hline Model pola asuh & f & \% \\
\hline Demokratis & 28 & 28.6 \\
Otoriter & 37 & 37.8 \\
Permisif & 33 & 33.6 \\
\hline
\end{tabular}

Berdasarkan tabel tersebut, diketahui bahwa lebih banyak orang tua responden yang menerapkan pola asuh otoriter terhadap anaknya yaitu sebesar $9.2 \%$ dibanding pola asuh demokratis dan $4.2 \%$ dibanding pola asuh permisif

\section{Gambaran perilaku bullying remaja di SMP 19 Kota Jambi}

Secara rinci gambaran perilaku bullying pada remaja di SMP 19 Kota Jambi dapat dilihat pada tebel berikut:
Tabel 3. Distribusi responden berdasarkan Perilaku Bullying

\begin{tabular}{lcc}
\hline \multicolumn{1}{c}{ Perilaku bullying } & f & \% \\
\hline Bullying fisik & 27 & 27.5 \\
Bullying verbal & 39 & 39.8 \\
Bullying psikologis & 32 & 32.7 \\
\hline
\end{tabular}

Secara umum diperoleh gambaran bahwa perilaku bullying yang sering dilakukan oleh remaja di SMP 19 Kota Jambi adalah bullying verbal (12.3\%) lebih banyak dari bullying fisik dan psikologis.

\section{Hubungan pola asuh dengan perilaku bullying remaja di SMP 19 Kota Jambi}

Secara statistik dapat dilihat hubungan antara pola asuh dengan perilaku bullying pada remaja di SMP Negeri 19 Kota Jambi pada tabel berikut:

Tabel 4. Hubungan Pola Asuh dengan Perilaku Bullying pada Remaja

\begin{tabular}{|c|c|c|c|c|c|c|c|c|c|c|}
\hline \multirow{3}{*}{ Pola asuh } & \multicolumn{6}{|c|}{ Perilaku Bullying } & \multirow{2}{*}{\multicolumn{2}{|c|}{ Jumlah }} & \multirow{3}{*}{$\alpha$} & \multirow{2}{*}{$P$ value } \\
\hline & \multicolumn{2}{|c|}{ Fisik } & \multicolumn{2}{|c|}{ Verbal } & \multicolumn{2}{|c|}{ Psikologis } & & & & \\
\hline & $\mathrm{f}$ & $\%$ & $\mathrm{f}$ & $\%$ & $\mathrm{f}$ & $\%$ & $\mathrm{f}$ & $\%$ & & \\
\hline Demokratis & 5 & 5.1 & 14 & 14.3 & 9 & 9.1 & 28 & 28.6 & & \\
\hline Otoriter & 9 & 9.1 & 18 & 18.4 & 10 & 10.2 & 37 & 37.7 & 0.05 & 0.037 \\
\hline Permisif & 5 & 5.1 & 13 & 13.3 & 15 & 15.3 & 33 & 33.7 & & \\
\hline Total & 19 & 19.3. & 45 & 46 & 34 & 34.6 & 98 & 100 & & \\
\hline
\end{tabular}

Berdasarkan hasil uji statistik tersebut bahwa dari pola asuh demokratis terdapat $14.3 \%$ remaja dengan perilaku bullying secara verbal, sementara itu pola asuh otoriter terdapat $18.4 \%$ remaja dengan perilaku bullying secara verbal, dan dari pola asuh permisif terdapat $15.3 \%$ remaja dengan perilaku bullying secara psikologis. Dari analisis tersebut dapat disimpulkan terdapat hubungan antara pola asuh dengan perilaku bullying pada remaja dengan nilai $p$ value $<0.05$

\section{Pembahasan}

Dalam mengasuh anak, orang tua cenderung menggunakan pola asuh tertentu. Terdapat tiga jenis pola asuh yaitu demokratis, otoriter, dan permisif. Pada tipe demokratis, orang tua memberikan kebabasan kepada anak untuk memilih melakukan suatu tindakan dengan sikap dan pendekatan orang tua yang hangat terhadap anak. Pola asuh otoriter diterapkan oleh orang tua yang tidak mengenal kompromi dan komunikasi selalu bersifat satu arah. Orang tua cenderung memaksa, memerintah dan menghukum apabila anak tidak menuruti perintahnya. Sementara tipe permisif, orang tua cenderung membiarkan dan tidak membimbing anak.

Pola asuh demokratis akan menghasikan karakteristik anak-anak yang mandiri, dapat mengontrol diri, mempunyai hubungan baik dengan teman, mampu menghadapi stress, mempunyai minat terhadap hal-hal baru dan koperatif terhadap orang-orang lain. Pola asuh otoriter akan menghasilkan karakteristik anak yang penakut, pendiam, tertutup, tidak berinisiatif, gemar menentang, suka melanggar norma, berkepribadian lemah, cemas dan menarik diri. Pola asuh permisif akan menghasilkan karakteristik anak-anak yang impulsive, agresif, tidak patuh, manja, kurang mandiri, mau menang sendiri, kurang percaya diri, dan kurang matang secara sosial (Rina M. Taufik, 2006).

Bentuk pola asuh yang diterapkan orang tua akan membentuk karakter anak yang akan terbawa saat anak berada diluar rumah bahkan sampai anak tumbuh dewasa. Pola asuh otoriter dan permisif memiliki kecenderungan yang besar terjadinya perilaku bullying pada anak. Tiga faktor utama yang mempengaruhi pola asuh adalah budaya dimana perbedaan latar belakang budaya orang tua dan orang tua tidak lagi memperhatikan nilai dan norma budaya yang baik, maka pola asuh yang diterapkan banyak memberi pengaruh negative terhadap perkembangan anak. Kemudian pendidikan orang tua, semakin tinggi pendidikan orang tua seharusnyalah akan semakin memperkaya wawasannya dalam memberikan pola asuh yang terbaik bagi anaknya, dan status sosial ekonomi keluarga juga menjadi andil besar bagaimana pola asuh yang diberikan, beban ekonomi berkepanjangan sangat berpeluang terjadinya pola asuh yang salah terhadap anak.

Hasil penelitian ini menunjukkan keterkaitan antara pola asuh dengan perilaku bullying . belum ada bentuk pola asuh yang sempurna, pola asuh demokratis sekalipun tidak menutup kemungkinan masih adanya perilaku bullying pada anak meskipun proporsinya tidak 
besar. Beberapa tindakan orang tua yang jarang disadari ternyata membentuk karakter perilaku bullying pada anak, seperti membuat anak sibuk dengan aktivitas dengan maksud menjauhkan anak dari masalah namun faktanya selain kelelahan anak juga bisa menjadi korban bullying. Kemudian kepintaran dianggap paling penting sehingga anak menjadi arogan dan menganggap orang lain bodoh, jika terlalu sering mengkritik, anak akan menuntut kesempurnaan dalam segala hal, saat ia melakukan kesalahan mereka merasa tidak berguna dan marah.

The American Mental Health Assosiation menyebutkan bahwa semua pola asuh memiliki tujuan akhir yang sama yaitu menumbuhkan anak yang disiplin dan bertanggung jawab. Pola asuh otoriter yang membuat semua aturan wajib diikuti oleh anak tanpa terkecuali, hal ini terkesan orang tua jarang menunjukkan sikap yang hangat pada anak dan cenderung dingin dalam menyikapi kebutuhan emosional anak. Saat merasa kecewa orang tua yang otoriter akan lebih banyak berteriak, dominan dan memaki anak meskipun dengan alasan demi kebaikan anak. Orang tua yang menerapkan pola ini merasa anak tidak memiliki hak untuk menyuarakan keputusannya sendiri, tidak melibatkan anak dalam membuat keputusan dengan alasan orang tua mengetahui apa yang terbaik. Sejatinya dengan pola asuh ini anak hidup dalam ketakutan dan merasa tertekan, sulit merasa bahagia, ada saatnya anak akan menunjukan perilaku pembangkang yang akan diperlihatkan saat berada di lingkungan pergaulan.

Pola asuh permisif dinilai oleh para ahli adalah pola asuh yang gagal karena tidak memiliki aturan. Studi menunjukkan anak-anak dari orang tua yang permisif lebih cenderung menunjukkan tanda-tanda kecemasan, depresi, agresi, memiliki keterampilan social yang buruk, dan prestasi yang buruk disekolah (Laura, M, 2016). Orang tua cenderung mengabaikan perilaku buruk anak, mereka menilai akan lebih baik ketika anak mereka marah karena dianggap dapat menyelesaikan masalah anak sendiri

Menurut analisis penulis, idealnya dalam menegakkan displin pada anak memang harus dilakukan dengan cara yang baik dan tegas dengan harapan anakanak dapat mengembangkan keterampilan menyelesaikan masalah, pengambilan keputusan, memiliki rasa empati, hormat, mampu melakukan control diri dan regulasi emosional, serta memiliki kepercayaan diri yang positif.

\section{SIMPULAN}

1. Anak-anak dengan perilaku bullying memiliki latar belakang pola asuh orang tua yang cenderung otoriter dan permisif

2. Sebanyak $39,8 \%$ perilaku bullying yang terjadi pada remaja adalah bullying verbal
3. Terdapat hubungan yang bermakna antara pola asuh dengan perilku bullying

\section{Saran}

1. Orang tua hendaknya bijak dalam menerapkan pola asuh yang tepat terhadap anak-anaknya, tentunya dengan memperhatikan tidak hanya aspek fisik semata namun juga harus mempertimbangan kebutuhan psikologis anak

2. Sekolah hendaknya memberdayakan fasilitas bimbingan konseling yang telah tersedia secara lebih optimal guna menghindarkan praktik bullying di sekolah

3. Sebaiknya meneliti varians variable lain yang mendukung terjadinya perilaku bullying pada remaja

\section{DAFTAR PUSTAKA}

Ahmed, E., Braithwaite, V. (2014). Bullying and victimization: cause for concern for both families andschool. Social Pshycology of Education, 7, 35 $-54$.

Annisa (2012). Hubungan antara pola asuh ibu dengan perilaku bullying remaja.Fakultas Ilmu

Keperawatan:Universitas Indonesia

Brooks, J. (2008). The Process of parenting. (7th ed.). New York: Pearson.

Kartono, K. (2014). Patologi Sosial II: Kenakalan Remaja. Jakarta: PT Rajagrafindo Persada.

Laura,M (2016). Peaceful Parent, Happy Kids

Murtiyani, N. (2011). Hubungan pola Asuh Orang Tua denganKenakalan Remaja di $R W V$ Kelurahan Sidokare Kecamatan Sidoarjo. Jurnal Keperawatan Vol. 1 No. 1 Januari 2011

O'Connel, J. (2003). Bullying at school. California: Departement of Education.

Santrock, J. W. (2007). Adolescence (2th ed.). Boston: McGraw-Hill.

Selly, Esrom, \& Hendro (2015). Hubungan Pola asuh orang tua dengan perilaku bullying pada remaja SMK N 1 Manado. E-journal eperawatan Vol.3

Yayasan Sejiwa amini (Sejiwa). (2010). Kekerasan terhadap anak makin memiriskan 